\title{
BÓG JAKO ALEGORIA KRÓLÓW: ZWOLENNICY I WROGOWIE ${ }^{1}$ \\ PAWEL ARMADA, ARKADIUSZ GÓRNISIEWICZ, KRZYSZTOF C. MATUSZEK [RED.], THE PROBLEM OF POLITICAL THEOLOGY \\ Robert Pawlik \\ Uniwersytet Kardynała Stefana Wyszyńskiego
}

Teologia polityczna to temat, który w ostatnich latach również w Polsce stał się przedmiotem żywego zainteresowania ${ }^{2}$. Jednak opinie o niej pozostają dość schematyczne i spolaryzowane. Przeciwnikom kojarzy się prawie wyłącznie z postacią Carla Schmitta, który swoją teologia polityczną chciał zakwestionować teorię polityczną liberalizmu, w miejsce reguły prawnej stawiając wyjątek i arbitralną decyzję suwerena. Ponieważ suwerena ujmuje on „w analogii” do Boga, teologia polityczna przedstawiana bywa jako fenomen regresywny, kwestionujący jedną z podstawowych zdobyczy nowoczesności: „wielką separacje” sfery religijnej od politycznej. Bywa poczytywana za chęć resakralizacji polityki i budowania jej na religijnych, chrześcijańskich podstawach. I rzeczywiście, takie wydają się intencje zwolenników pewnej odmiany teologii politycznej, krytykujących „nowożytny eksperyment" pozbawienia współczesnego ładu politycznego transcendentnej podstawy, co uważaja za główną przyczynę kruchości i rozlicznych bolączek tego ładu i czemu chcą zaradzić, ustanawiając „społeczne królestwo Chrystusa” (por. Bartyzel 2007).

\footnotetext{
${ }^{1}$ Tekst napisany w ramach grantu DSM 102600/10.

${ }^{2} \mathrm{O}$ czym świadczą choćby liczne przekłady prac na temat teologii politycznej: M. Lilla (2009). P. Valadier, (2010), J. Taubes (2010), M. Scattola (2011).
} 
To spolaryzowane spojrzenie na teologię polityczną jest w dużej mierze uproszczeniem. Teologia polityczna to fenomen wieloznaczny i o wiele bardziej złożony, który nie pojawił wraz z rozprawą Carla Schmitta w 1922 roku. Jak zauważył Heinrich Meier (2003-2004: 178), jej rodowód jest „,równie dawny jak religia objawiona”. Zwolennicy teologii politycznej - czy religii obywatelskiej - rekrutowali się nie tylko spośród tradycjonalistów czy monarchistów, ale również spośród teoretyków nowożytnej demokracji: byli wśród nich m.in. Jan Jakub Rousseau i Maksymilian Robespierre. Natomiast stosunek samego chrześcijaństwa do teologii politycznej, choć ewoluował, to zazwyczaj miał charakter zdecydowanie negatywny.

Zadanie naświetlenia problemu teologii politycznej w jego skomplikowaniu i różnorodności przyświecało międzynarodowej konferencji, która we wrześniu 2010 roku obradowała w Krakowie. Dotyczyła teologiczno-politycznych wątków w dziełach Homera, Hezjoda, Augustyna, Spinozy, w encyklice Piusa XI Quas Primas, a także u autorów XX-wiecznych, takich jak Erik Peterson, Dietrich von Hildebrandt, Leo Strauss czy wspomniany Carl Schmitt. Z plonami tej konferencji można się zapoznać dzięki publikacji zatytułowanej The Problem of Political Theology. Jak podkreśla jeden z redaktorów tomu, Krzysztof C. Matuszek (2012: 26), spojrzenie na dzieje teologii politycznej oraz historię niekończacych się sporów między religią a polityką można rozumieć jako refleksję nad jednym z ważniejszych źródeł zachodniej wolności. Albowiem choć przywykliśmy do wyobrażenia, iż oddzielenie Kościoła od państwa to dzieło nowoczesnej demokracji, to rzut oka na dzieje teologii politycznej pozwala dostrzec rolę samego chrześcijaństwa, które swoją stałą walką o autonomię od sfery politycznej sprzyjało wyłonieniu się polityki jako samodzielnej dziedziny (Nancy 2007: 4). Ponadto swym sprzeciwem wobec traktowania państwa jako ostatecznego i absolutnego autorytetu chrześcijaństwo miało swój wkład w stawianie dobra jednostki na równi z dobrem wspólnoty.

Jak każda obszerniejsza prezentacja teo-politycznych dziejów Zachodu The problem... sprzyja wielu ogólniejszym wnioskom. Zamiast omawiać poszczególne teksty, postaram się zrekonstruować wizję teologii politycznej, która się z tego dzieła wyłania. Motywem przewodnim uczynię ten aspekt jej dziejów, w którym teologia polityczna oznaczała sprzeciw wobec ubóstwiania wspólnoty politycznej oraz instrumentalizowania religii.

\section{/// II.}

Tom pokonferencyjny otwiera szkic Davida Janssensa (2012: 29-43), który zagadnienie splotu religii i polityki wyprowadza z poezji Homera 
i Hezjoda. I słusznie, bowiem - wbrew sugestii H. Meiera - można zasadnie twierdzić, iż w szerokim sensie problem teologiczno-polityczny dotyczył również starożytnej Grecji oraz Rzymu. Na pewno wyraźnie obecny był już u Platona, który w głębokim kryzysie greckiej polis (z całą moca ujawnionym w wojnie peloponeskiej) dostrzegł jego głębokie podłoże religijne. Osławiony pomysł wykluczenia poetów z najlepszego państwa (Państwo ks. III i X) wynikał częściowo z zarzutu, że poeci przekazuja błędne i szkodliwe wyobrażenia o bogach. Tradycyjne mity Homera i Hezjoda eksponują niestosowne zachowania bogów, z tego względu zdaniem Platona, sprawiedliwe państwo winno kontrolować „dyskurs teologiczny”, w którym ludzie znajdują usprawiedliwienie dla swoich wad ${ }^{3}$. Przyjmując, że wyobrażenia o bogach moga legitymizować lub delegitymizować konkretne zachowania ludzkie, ateński filozof pośrednio przyznał, że opowieści te nie należą do zagadnień neutralnych politycznie. Przeciwnie, teologia Platon najprawdopodobniej jest twórcą tego słowa, które po raz pierwszy odnajdujemy w dialogu Państwo (379a) - niesie ze sobą potencjal politycznie wybuchowy ${ }^{4}$.

Toteż Platon nie poprzestał na krytyce teologii poetów, ale w iście „kontrreformacyjnym” geście wypracował nowy język „mówienia o bogach” - swoista „nowa teologię”. Ponieważ musiała to być teologia odporna na zarzut „konwencjonalności” czy umowności, który wyobrażeniom religijnym stawiali wcześniejsi myśliciele, Platon zakorzenił język nowej teologii w fizyce. Timajos - dialog o powstaniu świata - jest zarazem dziełem teologicznym ${ }^{5}$ : opowieścią o kosmosie jako „bogu postrzegalnym zmysłami" (theos aisthetos, Tim. 92c). Bóg z Timajosa to zatem bóg kosmiczny. Ten konkurencyjny wobec teologii poetyckiej dyskurs teologiczny stoicy nazwą później „teologia naturalną". W ostatnich swych dziełach - Prawach (885b-887a) i Epinomis - ateński filozof zaproponuje, by ów kosmiczny bóg stał się obiektem kultu państwowego. Religia boga kosmicznego przejęłaby funkcję religii państwowej; w ten sposób nowym religijnym fundamentem ładu politycznego miałby stać się kult boskiego ładu kosmosu.

\footnotetext{
${ }^{3}$ Prekursorem Platona był tu Ksenofanes, o którym H. Schmidt (1968: 330) powiada: „odrzucił antropomorficzny politeizm homerowskiego świata bogów, który sankcjonował i utwierdzał dobra doczesne, obyczaje i stosunki przemocy tradycji arystokratycznej. Przeciwstawił temu uznanie jednego niezmiennego Boga, który był czystym, niezmiennym rozumem (nous), pozwalał poznać wieczny porządek, według którego kształtować się winno życie (bios) i państwo (polis)".

${ }^{4}$ Ten polityczny potencjał metafor teologicznych ze szczególną mocą w XX wieku akcentował Jacob Taubes (2013).

",Timajos" - ów dokument założycielski greckiej teologii kosmosu - jest zarazem dialogiem politycznym. Nie bez powodu otwiera go opowieść o dwóch miastach, znana jako „mit Atlantydy”, por. P. Vidal Naquet (2003).
} 
Problem teologiczno-polityczny ze szczególną ostrością objawił się także w dziejach Rzymu - miasta przeznaczonego „z woli opatrzności” do stania się państwem obejmującym cały świat i jednoczącym wszystkie ludy w pokoju i sprawiedliwości ${ }^{6}$. W dobie ostrego kryzysu, w obliczu toczących się wojen domowych i konfliktów społecznych związanych z integracja podbitych terenów i zamieszkujących je ludów, konfliktów, które w połowie I wieku p.n.e. wstrząały Rzymem, niektórzy rzymscy intelektualiści uznali, że skutecznym remedium na te trudności może być jedynie tradycyjna religia rzymska. Do takich osób należał Marek Terencjusz Warron, który swoim monumentalnym dziełem Antiquitates rerum bumanarum et divinarum z 47 roku p.n.e. dał silny impuls do odnowienia rzymskiej pobożności ${ }^{7}$. Za stoikami Warron wyróżnił trzy rodzaje teologii (tria genera theologiae) na podstawie trzech źródeł wiedzy o bogach ${ }^{8}$ : „teologię mityczna” uprawianą przez poetów, której domeną był teatr; „teologię naturalną” filozofów, widzących w dyskursie o bogach alegoryczne przedstawienie sił kosmicznych czy naturalnych oraz, uznana przez siebie za najważniejszą, „teologię cywilną" czy obywatelska (theologia civilis), przez którą rozumiał kult państwowy uprawiany przez kapłanów i obywateli. Do rangi wiedzy wyniósł on zatem system reguł i publicznych rytuałów służących utrzymaniu pax deorum - pokoju między Rzymianami a ich bogami (por. J. Rüpke 2005: 118). Ten trzeci rodzaj teologii - teologia obywatelska, to po grecku, jak zaświadcza św. Augustyn, tyle co teologia polityczna (theologia politkie) ${ }^{9}$.

Nie ma wattpliwości, że zarówno w Grecji, jak i w Rzymie wspólne wyobrażenia o bogach stanowiły spoiwo konsolidujace wspólnotę polityczna. Wspólnota wyrastała z kultu, składanych wspólnie ofiar rytualnych oraz ceremoniałów, dzięki którym konstytuowała swoja tożsamość. Warron jak przed nim Platon - krytykował teologię mityczna poetów. Dostrzegając wartość teologii naturalnej, polegającą na jej uniwersalności, za najważniejszą dla Rzymu uznał jednak teologię obywatelską, pomimo tego że różniła

\footnotetext{
${ }^{6}$ Kanoniczne sformułowanie ideologii dziejowej misji Rzymu spotykamy w Eneidzie, w słowach Jowisza: „Im w przestrzeni, i w czasie żadnej granicy nie kładę: bezkresne dałem panowanie” (1.279), oraz Anchizesa: „Ty, Rzymianinie, pamiętaj: masz władnie rządzić ludami. Te są twoje kunszty: masz pokojowi nadać prawo, szczędzić poddanych, wojną poskramiać zuchwałych" (6. 851-853).

${ }^{7}$ Pierwszym wielkim propagatorem teologii politycznej w republikańskim Rzymie był pontifex maximus Kwintus Mucjusz Scewola. O odrodzeniu religijnym w czasach późnej republiki i wczesnego cesarstwa, którego ślady odnajdujemy w De natura deorum Cycerona oraz w poezji Wergiliusza i Owidiusza (Fasti), zob. Momigliano 1984.

${ }^{8}$ Dzieło Warrona zaginęło. Jego trójpodział teologii znamy dzięki Tertulianowi (Do pogan, II, 1-9) oraz św. Augustynowi (O państwie Bošsym VI.5).

${ }^{9}$ "Nunc propter tres theologias, quas Graeci dicunt mythicen physicen politicen, Latine autem dici possunt fabulosa naturalis civilis" (O państwie Bo šym VI, 12).
} 
się dla każdego ludu i miasta ${ }^{10}$. Jako theologus civilis Warron nie dbal jednak o prawdziwość czy fałszywość wyobrażeń religijnych, o ile spełniały swe zadanie i służyły integracji wspólnoty. W religii politycznej liczy się wyłącznie jej użyteczność, czyli funkcja wspólnototwórcza, której teologia naturalna, jako nadto wyrafinowana, nie byłaby w stanie zagwarantować.

$\mathrm{Na}$ tle rzymskiego pojmowania religii wyraźnie widać przełom, jaki przyniosło ze sobą chrześcijaństwo. Wprowadza ono nowe wyobrażenie boskości i zbawienia, a także samej religii i teologii. Między innymi odrzuca pojmowanie religii jako głównego narzędzia tworzenia ciagłości i tradycji społecznej ${ }^{11}$. Przez religię pierwotne chrześcijaństwo rozumiało coś innego - indywidualny i wewnętrzny akt nawrócenia; dokonującą się, w odpowiedzi na wezwanie Boga, dogłębną wewnętrzną przemianę, z której wynika przeobrażenie dotychczasowego sposobu odniesienia do świata, w tym także stosunek do prawa i państwa. Wewnętrzna metanoia przynosi wyraźne zerwanie, a nie kontynuację. Dowartościowany zostaje wymiar prawdziwości. Nawraca się bowiem na to, co „prawdziwe”, a nie - co użyteczne społecznie.

Religia, w rozumieniu pierwszych chrześcijan, skutkuje nie tyle przywiązaniem do tradycji, ile wewnętrzną rewolucją i początkiem czegoś całkowicie „nowego" ${ }^{12}$. Wprawdzie doświadczenie to przekłada się na wspólnotę, ale jest to nowy rodzaj wspólnoty. W Kościele już „nie ma Żyda ani Greka, nie ma niewolnika ani wolnego, nie ma mężczyzny ani kobiety" (Gal 3,28), czyli zniesione zostają różnice narodowe, płciowe i społeczne oraz konstytutywne dla wspólnoty politycznej podziały i hierarchie. Oznacza to, że chrześcijaństwo przynosi zbawienie dla wszystkich, nie ma jednak charakteru politycznego i nie wpływa na wzmocnienie lojalności wobec domeny politycznej.

Chrześcijaństwo tak rozumiane nie mogło poddać się rzymskiej religii obywatelskiej, ceremoniom i obrzędom w służbie spójności imperium. Odrzucenie kultu cesarza to jedna z przyczyn, dla której zostało uznane za religio illicita. W oczach konserwatywnego intelektualisty rzymskiego z II wieku - Celsusa - chrześcijaństwo jawiło się jako zaprzeczenie religii

\footnotetext{
${ }^{10}$ Niekiedy twierdzi się (np. P. Van Nuffelen, 2010), że dla Warrona theologia civilis i theologia naturalis są ze sobą tożsame.

${ }^{11}$ Chrześcijaństwo oznaczało zerwanie z rzymską koncepcją religijności: przez obietnicę indywidualnego zbawienia oraz wiarę postawioną w miejsce praktyk rytualnych było religia , wyjścia z religii” (Gauchet). Por. Sachot 1998; Stroumsa 1999.

${ }^{12}$ Jak przypomina Tertulian: „nikt nie rodzi się chrześcijaninem, tylko się nim staje” (Fiunt, non nascuntur Christiani) Tertulian, Apologetyk (18.4).
} 
w ogóle i stanowiło fenomen bezbożny czy ateistyczny ${ }^{13}$. Celsus podkreślał „buntownicze usposobienie” chrześcijan, którzy dopuścili się podwójnej nielojalności. Po pierwsze, „odłączyli się od Żydów”, od których się wywodzą (tak jak kiedyś Żydzi zbuntowali się przeciw Egipcjanom, tak teraz chrześcijanie zbuntowali się przeciw Żydom) (por. Orygenes, Przecin Celsusowi, III. 5 oraz V. 33), a także swym monoteizmem zbuntowali się przeciw Imperium Romanum. Myślący w kategoriach religijności obliczonej na wspieranie wspólnoty politycznej, Celsus dostrzega zagrożenie kryjące się w chrześcijańskim monoteizmie. Oznacza on bowiem atak na bogów, którzy byli gwarantem pomyślności Rzymu. Eliminując wielobóstwo - konstytutywną postać rzymskiej pietas - podważało rzymski porządek polityczny.

Rozkład politeizmu był zagrożeniem dla ufundowanego na nim Rzymu. Chrześcijanie, wprowadzając swego najwyższego Boga, odmawiali czci pomniejszym bóstwom. Lekceważyli w ten sposób opiekunów poszczególnych ludów, okazując wzgardę wobec lokalnych praw oraz zwyczajów ${ }^{14}$. A przecież - powiadał Celsus - różne części ziemi zostały oddane pod zarząd różnym zwierzchnościom jako ich własność, toteż podlegały ich władzy (Por. Orygenes, Przecin Celsusowi V.32; VIII.35). Nawet gdy uznajemy najwyższego Boga, nie zwalnia to nas $z$ oddawania czci bóstwom lokalnym, bowiem najwyższy Bóg nie rządzi samodzielnie, ale przez zależne od niego „potęgi”. Jest niczym perski satrapa, który wprawdzie posiada władzę, ale imperium swym zarządza za pośrednictwem urzędników. „Najwyższy Bóg sprawuje władzę, ale rządzą narodowi bogowie", tak można streścić argument Celsusa, który zapowiada już maksymę Le roi règne, mais il ne gouverne pas, którą XX-wieczny teolog niemiecki Erik Peterson (2012) uznał za kwintesencje ,teologii politycznej pogaństwa" ${ }^{15}$.

Celsus uwypuklił związek wielobóstwa ze strukturą systemu imperialnego. Chrześcijańska reakcja na jego tezy wyszła blisko sto lat później

\footnotetext{
${ }^{13}$ Ateistami dla Rzymian byli wszyscy, którzy nie składali ofiar bogom i nie uczestniczyli w kulcie państwowym. Zarzut ateizmu sformułowany pod adresem chrześcijan znał już Justyn Męczennik, Apologia, (1. 6.1).

${ }^{14}$ Często spotykane oskarżenie chrześcijan o lekceważenie mos majorum to zarzut odrzucania tradycji przodków, braku korzeni, zerwania.

${ }^{15}$ Polityczna funkcja politeizmu, oprócz ugruntowania posłuszeństwa wobec prawa i obyczajów, polegała na odwzorowaniu na planie boskim różnic i tożsamości, z których składał się świat społeczny. Politeizm oznaczał zatem afirmację dystynkcji między narodami, prowincjami, miastami czy grupami społecznymi. Fakt ten skłaniał niektórych interpretatorów do dostrzeżenia w politeizmie swoistej aktualności dla pluralistycznego świata późnej nowoczesności (por. Marquard 1994). Na chrześcijańskie przezwyciężenie różnic narodowych i nacjonalizmów zwraca uwagę E. Peterson (1959).
} 
spod pióra Orygenesa. Dojrzalszą postać jego argumentom nadał uczeń Orygenesa, biskup Cezarei, Euzebiusz. Dokonał tego w odmienionej sytuacji historycznej, a mianowicie kiedy chrześcijaństwo stawało się już religio licita. Jego argumenty zmierzały do wykazania bliźniaczego przeznaczenia chrześcijaństwa i Rzymu. Orygenes i Euzebiusz dowodzili, że na świecie pokój zapanował dopiero za panowania cesarza Augusta, który pokonał waśnie i doprowadził Rzym do jedności - a wielość bóstw i różnorodność ludów sprzyjała raczej wojnom i podziałom. Natomiast jednowładztwo monarchia polityczna - okazało się warunkiem zaistnienia pokoju. Według Euzebiusza fakt, że Chrystus - monoteistyczny Bóg - przyszedł na świat w momencie, gdy monarchia Augusta zaprowadziła pokój, był wymownym potwierdzeniem, iż losy chrześcijaństwa i Rzymu są ściśle splecione. W ten sposób monarchia polityczna włączyła się w „monarchię Bożą", to znaczy w monoteizm chrześcijański (,monoteizm” to termin nowożytny; Euzebiusz i inni autorzy posługiwali się wówczas wyrażeniem „monarchia Boża”). Jednowładztwo polityczne zbiegło się w czasie z rządami jednego Boga nad światem.

Trzysta lat po narodzeniu Chrystusa, pod koniec życia Euzebiusza gdy monarchia Konstantyna zastąiła tetrarchię Dioklecjana - związek monoteizmu („monarchii Bożej”) z monarchią cesarstwa rzymskiego jawił się jeszcze wyraźniej. W swej historiozoficznej wizji Euzebiusz dostrzegł nałożenie się obu procesów: pierwszego, reprezentowanego przez chrześcijaństwo, które doprowadziło do przezwyciężenia politeizmu, oraz drugiego, w którym imperium rzymskie (tj. monarchia) pokonało „poliarchię” oraz ,anarchię”. Pokój w niebie, zaistniały wraz z narodzeniem Jezusa, oraz pax Romana, zaprowadzony przez Augusta, złączyły się w chrześcijańskim imperium rzymskim. Ten nowo urzeczywistniony pokój to nic innego jak zapowiadany w Psalmach (71.7) czy przez Izajasza (Iz 2.4.) pokój mesjański. Zgodnie z teorią Euzebiusza Imperium Romanum - cesarz August, ale zwłaszcza cesarz Konstantyn - odegrało kluczową rolę w bożym planie zbawienia ludzkości. Przyczyniło się do urzeczywistnienia królestwa mesjańskiego. W ten sposób rodzaj ludzki rozproszony wskutek grzechu został doprowadzony do jedności. Przestały istnieć państwa narodowe (zjednoczone w cesarstwie rzymskim), a dzięki wierze w jednego Boga, tj. jednego monarchę w niebie, zniknęły pogańskie religie z ich bóstwami. Dlatego chrześcijaństwo narzuca się jako „konieczne” uzupełnienie pełnego zjednoczenia imperium rządzonego przez jednego monarchę ziemskiego. Potęga imperium już na Ziemi przyczynia się do zjednoczenia ludzkości, które - według nauki chrześcijańskiej - miało się urzeczywistnić dopiero w wymiarze eschatologicznym. 
Innym ważnym posunięciem Euzebiusza było zaadaptowanie na potrzeby chrześcijaństwa hellenistycznej teorii politycznej, wedle której władca jest obrazem Boga na Ziemi (por. Cranz 1952, Goodenough 1928). W „Mowie na cześć Konstantyna” biskup Cezarei tłumaczył, że cesarz rzymski jest naśladowcą Logosu (Chrystusa). Władza cesarza nie tylko wywodzi się od Boga, ale cesarz jest także ziemskim odwzorowaniem władzy jedynego Boga w niebie, a konkretnie odzwierciedleniem władzy Chrystusa. Euzebiusz przeprowadził tu uderzającą analogię: jeden Bóg i jedno prawo (Logos-Chrystus) w niebie, jeden władca i jego prawo na Ziemi ${ }^{16}$.

Alians monoteizmu chrześcijańskiego i monarchii politycznej to próba uczynienia z chrześcijaństwa nowej religii obywatelskiej Rzymu. Chrześcijaństwo ze swym kultem jednego Boga wydało się cesarzowi rzymskiemu nowa, skuteczniejszą podstawą dla jego jednowładztwa, toteż wyznaczył chrześcijaństwu rolę, którą dotychczas pełniła w imperium religia państwowa.

W świetle koncepcji Euzebiusza Chrystus, nauczając o „jednowładztwie" Boga, utwierdził jednowładztwo Rzymu. Co więcej, dzięki chrześcijańskiemu cesarstwu rzymskiemu, drugie przyjście Chrystusa właściwie stawało się zbędne. $Z$ tej perspektywy dokonanie św. Augustyna polegało na stworzeniu przeciwwagi dla wizji Euzebiusza i na powrocie na pozycje wczesnochrześcijańskie. W następstwie traumatycznych wydarzeń związanych ze złupieniem Rzymu przez armie gockie w sierpniu 410 roku oraz kierowanymi pod adresem chrześcijan oskarżeniami o przyczynienie się do osłabiania potęgi Rzymu, biskup Hippony stworzył zręby chrześcijańskiego stanowiska na temat relacji chrześcijaństwa do dziedziny politycznej. Stanowisko to zawarł w swym głównym dziele O państwie Bo:̇ym, prezentując je w ramach polemiki z rzymska theologia civilis, zwłaszcza z koncepcjami Warrona. Chrześcijaństwa nie można zredukować do poziomu religii wspierającej cesarstwo, nowej skuteczniejszej religii państwowej czy teologii obywatelskiej, z tej racji, że chrześcijanie nie mają na tej Ziemi swojej ojczyzny; jako „pielgrzymi” nie mogą się w pełni utożsamiać z żadnym ładem politycznym, nawet tak imponującym jak porządek rzymski.

Augustyn dowodził, że dziedzina polityczna nie jest w stanie zapewnić człowiekowi prawdziwego szczęścia i pokoju. Podkreślał, że za Augusta wcale nie ustały wojny - było to niemożliwe, gdyż wszelka wspólnota

\footnotetext{
${ }^{16} \mathrm{~W}$ „Mowie na cześć Konstantyna” Euzebiusz powiada, że cesarz „układa [...] swe ziemskie rządy zgodnie z wzorem Boskiego oryginału, czując siłę w zgodności ich z monarchią Bożą [...], gdyż z pewnością monarchia przewyższa każdy ustrój i każdą formę rządu, ponieważ jej przeciwieństwo, demokratyczną równość władzy, można raczej określić jako anarchię i nierząd" (cyt. za Ch.N. Cochrane 1960: 189).
} 
polityczna zbudowana jest na rywalizacji i wzajemnej wrogości. Dążenie do uznania i chwały oraz podporządkowania sobie innych jest podstawowym mechanizmem napędzającym życie społeczne. Owo libido dominandi jest tym rodzajem zła, którego państwo nie jest w stanie przezwyciężyć, gdyż jest na nim ufundowane. Owa szkoła próżności i zawiści nie może prowadzić do szczęśliwości i pokoju. W kategoriach religijnych trzeba uznać, że państwo - civitas terrena - wzniesione jest na diabolicznej chęci zawłaszczania i zbrodni, czemu Biblia dała wyraz, czyniąc z bratobójcy Kaina twórcę pierwszego miasta ${ }^{17}$. Na takim grzesznym fundamencie nie da się zbudować trwałego pokojowego współżycia między ludźmi.

Według Augustyna żadne państwo ziemskie nie może stać się królestwem mesjańskim. Chrześcijanie należą do innego porządku - eschatologicznego państwa Bożego. Tylko w tym transcendentnym królestwie, gdzie władza pojęta jest jako służba, a rywalizację o uznanie zastapi miłość bliźniego, można odnaleźć pokój i szczęśliwość. Koncepcja państwa Bożego symbolizuje naukę o ludzkiej transcendencji - o tym, że żaden porządek polityczny nie wyczerpuje prawdy o człowieku, która wykracza poza to, co skończone. Oczywiście Augustyn nie chciał w ten sposób unieważnić porządku politycznego. Królestwo Boże nie likwiduje wymiaru politycznego, ale znacząco go relatywizuje. Rzeczywistość polityczna przestaje być czymś ostatecznym, absolutnym czy świętym. Królestwo Boże oznacza desakralizację dziedziny politycznej.

Ażeby zdyskredytować religię rzymską i pogańską teologię obywatelską, które instrumentalnie wykorzystywały religię $\mathrm{w}$ celu podbudowania ładu imperium, Augustyn posłużył się dziełem Warrona. Argumentował, że jego teologia obywatelska nie różni się zasadniczo od teologii mitycznej. Tym samym bogom, których wymyślili poeci i których ogląda się w teatrze, oddaje się cześć w rzymskich świątyniach. Zatem skoro teologia poetycka jest fałszywa - co przyznawał sam Warron - to fałszywa musi być także oparta na niej teologia obywatelska.

Strategia Augustyna polegała zatem na teologicznym zanegowaniu roszczeń Rzymu do sfery sacrum. Rzym - i sfera polityczna jako taka - nie maja sakralnych podstaw. Nie legitymizuja go pogańscy bogowie, o których opowiada się zmyślenia (O państwie Bošzym, VI. 9). Nie legitymizuje go także chrześcijaństwo, które ze swej istoty nie może być częścią ziemskiego porządku politycznego. Oczywiście, w tym teologicznym geście

\footnotetext{
${ }^{17} \mathrm{Na}$ kwestię zła jako ważny wymiar problemu teologii politycznej, a zarazem kwestię, której wyparcie stanowi sam rdzeń projektu nowoczesności, podczas krakowskiej konferencji zwrócił uwagę Michał Łuczewski (2012: 199-219).
} 
św. Augustyna można doszukać się intencji politycznych i uznać go za swoista odmianę teologii politycznej. Zamiast rzymskiego teologicznego utwierdzania polityki Augustyn wprowadza teologiczne dystansowanie się wobec niej - odmawia cesarstwu szczególnej roli w ekonomii zbawienia. Niekiedy taką postawę nazywa się „negatywną teologia polityczną” ${ }^{18}$.

Do teologiczno-politycznej polemiki Augustyna z Euzebiuszem warto dodać jeszcze jeden argument, który przypomniał XX-wieczny teolog niemiecki, Erik Peterson. W traktacie Monoteizm jako problem polityczny wykazał on, że chrześcijańska teologia polityczna jest niemożliwa z tego względu, iż fundamentalna dla rozumowania Euzebiusza analogia między monoteizmem (jednym władcą niebieskim) a monarchia (jednym władca ziemskim) została zlikwidowana już na poziomie ortodoksyjnego sformułowania dogmatu Trójcy Świętej (Peterson 2012:58). Teologowie kapadoccy, w odpowiedzi na ariańskie (,monarchianistyczne”) próby podporządkowywania Syna i Ducha Świętego osobie Ojca, sformułowali doktrynę Trójjedyności Boga wykluczająca jego polityczne wykorzystanie do usprawiedliwiania jednowładztwa ${ }^{19}$. Wszelkie usiłowania stopienia autorytetu świeckiego z boskim i wspieranie porządku państwowego autorytetem Boga, zdaniem Petersona, z góry sytuują się po stronie pogaństwa. Teologia polityczna to zdrada wiary chrześcijańskiej. Wprawdzie może istnieć pogańska i żydowska teologia polityczna, ale dogmat trynitarny ostatecznie likwiduje możliwość wszelkiej chrześcijańskiej teologii politycznej (Peterson 2012: 58) ${ }^{20}$.

\footnotetext{
${ }^{18}$ Pojęcie „negatywnej teologii politycznej” spopularyzował Jacob Taubes, używając go przede wszystkim w odniesieniu do Pawłowej krytyki prawa, ale także do myśli św. Augustyna, Lutra i Karla Bartha, (zob. Hartwich, Assmann i Assmann 2010: 212-221).

${ }^{19}$ Największe zagrożenie stojące przed pierwotnym chrześcijaństwem polegało na tym, że wchłonie w siebie symbole, idee oraz formy świata pogańskiego, przejmując również funkcję dawnej rzymskiej religii obywatelskiej. Wówczas stałoby się religią Boga, który zbawia wspólnotę polityczną zapewniając jej pomyślność, pokój i bezpieczeństwo. Toczące się w tamtym czasie spory trynitarne to nic innego jak chęć uwypuklenia wyjątkowości chrześcijaństwa. Ustanowienia Syna Bożego przeciw ariańskiej idei Chrystusa-Logosu, to sprzeciw wobec redukowaniu chrześcijaństwa do form pogańskich (neoplatońskich). Przy tej okazji zlikwidowana została również analogia między Bogiem (władcą niebieskim) a władca ziemskim, czyli wyobrażenie, że cesarz panuje w imieniu Boga.

Natomiast tam, gdzie chrześcijanie przejmowali obrazy pogańskie, nadawali im zazwyczaj radykalnie odmienny sens. Tak było w wypadku wyobrażenia Chrystusa Króla lub Chrystusa Imperatora, który pojawia się w „Księdze Apokalipsy” oraz u pisarzy wczesnochrześcijańskich. Przed Konstantynem wyobrażeniem tym posługiwano się dla sprzeciwienia się absolutyzmowi władzy cesarzy rzymskich. Chrystus Król to wyzwoliciel, który uwalnia swych wyznawców z podległości wobec wszelkiej władzy ziemskiej. E. Peterson (2012a: 16) pisał: „Chrystus, który jest cesarzem, i chrześcijanie należący do militia Christi to symbole walki o eschatologiczne imperium, które przeciwstawia się wszystkim imperiom tego świata”. Polityczny charakter symboliki „Księgi Apokalipsy” wyraża „opozycję wobec kultu cesarzy”. Chrystologia polityczna chrześcijaństwa zrodziła się z chęci zanegowania politycznej religii Rzymu.

${ }^{20}$ Pomimo swojej „niemożliwości teologicznej” teologia polityczna w formie politycznej chrystologii była rozpowszechniona w średniowieczu. Króla uważano wówczas za obraz Chrystusa na Ziemi,
} 
Traktat Petersona - który otwiera modlitwa do św. Augustyna ${ }^{21}-$ ukazał się w roku 1935, gdy od dwóch lat rozmaite środowiska religijne (zarówno protestanckie, jak i katolickie) w Niemczech podejmowały próby wspierania reżimu Hitlera. Toteż wskazanie przez Petersona na „teologiczną niemożliwość" wszelkiej chrześcijańskiej teologii politycznej miało w tamtym czasie charakter aktu jawnie politycznego. Wymierzony był w pierwszej kolejności w tzw. teologię Rzeszy, ale także w poglądy Carla Schmitta (dawnego przyjaciela Erika Petersona), który już w 1933 roku aktywnie włączył się w prawne usprawiedliwianie poczynań nazistów. W roku 1934 Schmitt, w symbolicznym geście wznowienia swojej rozprawy zatytułowanej Teologia polityczna. Cztery rozdzialy poświecone nauce o suwerenności, usiłował - również przy użyciu argumentu teologicznego - przywrócić range pojęcia suwerennej władzy dla współczesnego państwa. W traktacie tym Schmitt dowodził, że nawet w systemie liberalnym, pomimo „rządów prawa”, istnieje suweren, który w sytuacji kryzysowej „decyduje o stanie wyjątkowym”, czyli czasowym zwieszeniu tego prawa. Do zażegnania kryzysu nieodzowne okazuje się wprowadzenie stanu wyjątkowego, który „ma dla nauki o prawie analogiczne znaczenie jak cud w naukach teologicznych" ${ }^{22}$, tj. który rozumie się jako czasowe zawieszenie przez Boga obowiązywania praw natury. Tym samym Schmitt posłużył się Euzebiuszową analogią między suwerenem (monarcha) a Bogiem.

Odwołanie się Schmitta do teologii politycznej i teologicznego wsparcia dla suwerennej władzy nie było w czasach nazizmu zupełną nowością. Niemiecki jurysta nie potrzebował w tym celu sięgać ani do Euzebiusza, ani do wzorów rzymskich. Nawiązywał wprost do myślicieli kontrrewolucji: de Maistre’a, Bonalda, a zwłaszcza do Donoso Cortésa, którzy w celu zanegowania rewolucji francuskiej dokonali wielkiej rehabilitacji pojęcia teologii politycznej (Schmitt 2000: 73-83). Przeciwstawiając się teoriom umowy społecznej, która - ich zdaniem - czyniła z państwa twór sztuczny, a przez to również nietrwały, oraz występując przeciw futurystycznym społecznym utopiom, myśliciele ci zwrócili się ku temu, co minione

\footnotetext{
przypisując mu nawet „dwa ciała” na wzór dwóch natur Chrystusa. Chrześcijański król wywodził swą prawowitość z liturgicznego obrzędu namaszczania olejem świętym w trakcie ceremonii konsekracji. Dzięki tej ceremonii, zbliżonej charakterem do namaszczenia kapłańskiego, stawał się „pomazańcem” - figura czy obrazem Chrystusa oraz jego „namiestnikiem” (vicarius Christi) na Ziemi (zob. także Kantorowicz 2007).

${ }^{21}$ „Niech św. Augustyn, którego obecność dało się wyczuć we wszystkich duchowych i politycznych przemianach Zachodu, swymi modlitwami dopomoże czytelnikom oraz autorowi tej książki!” (Peterson 2012: 39). Peterson również kończy swe rozważania odwołaniem do Augustyna (Peterson 2012: $57-58)$.

${ }^{22}$ C. Schmitt, Teologia polityczna, dz. cyt., 61.
} 
i dobrze ugruntowane - ku tradycji. Sztuczności i prowizoryczności umowy przeciwstawili trwałe, bo „naturalne” społeczeństwo czy naród, które konstytuują się nie na mocy decyzji, lecz wzrastają w sposób organiczny w procesie historycznym. Za najważniejszy katalizator rozwoju i podporę dla tak pojętego narodu uważali religię. „Żadna instytucja nie może być trwała, jeżeli nie jest oparta na religii”' ${ }^{23}$ - powie de Maistre, mając na myśli również to, że religia chrześcijańska wydawała się w ówczesnej sytuacji jedynym gwarantem ciagłości, trwałości i autorytetu. Paradoksalnie de Maistre zgadzał się w tej kwestii ze swym wielkim adwersarzem, Janem Jakubem Rousseau, który w 8 rozdziale IV księgi Umony społecznej stwierdził: „religia zawsze była podwaliną nowo zakładanych państw". Wbrew de Maistre’owi Rousseau dodał jednak, że akurat religia chrześcijańska do tego celu wybitnie się nie nadaje: „chrześcijaństwo bardziej szkodzi, niż sprzyja silnemu ustrojowi państwa” (Rousseau 1966: 157). I przypomniał, że „poganie uważali zawsze chrześcijan za prawdziwych buntowników" (Rousseau 1966: 155). Rousseau przyznawał rację Machiavellemu, Monteskiuszowi, Hume’owi czy Gibbonowi, którzy widzieli w chrześcijaństwie rozbicie monistycznej identyfikacji religii z państwem, a ideał indywidualnego zbawienia uznawali za szkodliwy dla wychowywania dobrych obywateli. Dodawał, że „ciagły spór o jurysdykcję, [...] uczynił niemożliwą w państwach chrześcijańskich wszelką dobra politia” (Rousseau 1966: 155). Tak jak wielu innych nowożytnych myślicieli politycznych z sympatią spoglądał na rzymską teologię obywatelska jako na wzorzec nowoczesnych rozwiązań politycznych ${ }^{24}$. Wszyscy oni - zarówno nowożytni zwolennicy religii obywatelskiej, którzy postulowali wsparcie instytucji państwa przez kult istoty najwyżej, jak i tradycjonaliści działający $\mathrm{w}$ imię teokratycznego podporządkowania sfery politycznej religii chrześcijańskiej - mniej lub bardziej wyraźnie opowiedzieli się po stronie Warrona przeciw Augustynowi.

\section{Bibliografia:}

/// Armada P., Górnisiewicz A., Matuszek K.C. red. 2012. The Problem of Political Theology, Akademia Ignatianum, Wydawnictwo WAM, Kraków.

/// Augustyn. 1977. O państwie Bożym, tłum. W. Kornatowski, Instytut Wydawniczy PAX, Warszawa.

\footnotetext{
${ }^{23}$ De Maistre, Considérations sur la France, cyt. za: Trybusiewicz 1968: 76.

${ }^{24}$ Rousseau, choć z aprobatą wypowiada się o religii rzymskiej, to jako ideał stawia bezużyteczną politycznie „religię człowieka” - religię czystej wewnętrzności: bez świątyń, ołtarzy, obrządków i dogmatów.
} 
/// Bartyzel J. 2007. Społeczne Panowanie Chrystusa Króla w tradycyjnym nauczaniu Kościoła, „Pro Fide Rege et Lege” 2007, nr 2, s. 35-52.

/// Cochrane Ch.N. 1960. Chržeścijaństwo i kultura antyczna, tłum. G. Pianko, Instytut Wydawniczy PAX, Warszawa.

/// Cranz F.E. 1952. Kingdom and Polity in Eusebius of Caesarea, „Harvard Theological Review" 1952, nr 1, s. 47-66.

/// Goodenough E.R. 1928. The Political Pbilosophy of Hellenistic Kingship, „Yale Classical Studies” 1928, s. 55-102.

/// Górnisiewicz A. 2012. The Problem of the Closure of any Political Theology: Remarks on the Controversy between Erik Peterson and Carl Schmitt, [w:] The Problem of Political Theology, Górnisiewicz A., Armada P., Matuszek K.C. red., Akademia Ignatianum, Wydawnictwo WAM, Kraków, s. 45-57.

/// Hartwich D., Assmann A., Assmann J. Postowie [w:] J. Taubes (2010), s. 209-255.

/// Janssens D. 2012. Violent Grace: The Theologico-Political Problem in Ancient Poetry and Philosophy, [w:] The Problem of Political Theology, Górnisiewicz A., Armada P., Matuszek K.C. red., Akademia Ignatianum, Wydawnictwo WAM, Kraków, s. 29-43.

/// Justyn Męczennik. 2012. Apologia, 1. 6.1, tłum. L. Misiarczyk, Wydawnictwo UKSW, Warszawa.

/// Kantorowicz E. 2007. Dwa ciata króla. Studium ze średniowiecznej teologii politycznej, tłum. M. Michalski, A. Krawiec, Wydawnictwo Naukowe PWN, Warszawa.

/// Lilla M. 2009. Bezsilny Bóg. Religia, polityka i nowoczesny Zachód, tłum. J. Mikos, W.A.B., Warszawa.

/// Luczewski M. 2012. The Sleep of Monsters Produces Reason, [w:] The Problem of Political Theology, Górnisiewicz A., Armada P., Matuszek K.C. red., Akademia Ignatianum, Wydawnictwo WAM, Kraków, s. 199-219.

/// Marquard O. 1994. Pochwała politeizmu. O monomityczności i polimityczności, tłum. K. Krzemieniowa, [w:] Rozstanie z filozofia pierwsyych zasad, Oficyna Naukowa, Warszawa, s. 92-119.

/// Meier H. 2003-2004. Caym jest teologia polityczna? Wstęne uwagi na temat kontrowersyjnego pojecia, tłum. M. Kurkowska, „Teologia Polityczna” 20032004 , z. 1, s. 178-184. 
/// Momigliano A. 1984. The Theological Efforts of the Roman Upper Classes in the First Century B.C., „Classical Philology” 1984, nr 3, s. 199-211.

/// Nancy J-L. 2007. Church, State, Resistance, ,Journal of Law and Society” 2007, nr 1, s. 3-13.

/// Orygenes. 1986. Przecin Celsusowi, tłum. S. Kalinkowski, Akademia Teologii Katolickiej, Warszawa.

/// Peterson E. 1959. Das Problem des Nationalismus im Alten Christentum, [w:] Frübkirche, Judentun und Gnosis, Herder, Freiburg im Breisgau, s. 51-63.

/// Peterson E. 2012a. Chrystus jako imperator, tłum. T.M. Myśków, „44. Magazyn Apokaliptyczny" 2012, z. 4. s. 11-21.

/// Peterson E. 2012b. Monoteizm jako problem polityczny, ttum. J. Duraj, „Res Publica Nowa" 2012, nr 210, s. 38-61.

/// Platon. 1948. Państwo, tłum. W. Witwicki, Wiedza, Warszawa.

/// Platon. 1960. Prawa, tłum. M. Maykowska, PWN, Warszawa.

/// Rousseau J.J. 1966. Umowa społeczna, tłum. A. Peratiatkowicz, PWN, Warszawa.

/// Rüpke J. 2005. Varro's tria genera theologiae: Religious thinking in the late Republic, „Ordia prima” 2005, nr 4, s. 107-129.

/// Sachot M. 1998. L'invention du Christ. Genèse d'une religion, Odile Jacob, Paris.

/// Scattola M. 2011. Teologia polityczna, tłum. P. Borkowski, Instytut Wydawniczy PAX, Warszawa.

/// Schmidt H. 1968. Uwagi $i$ rapytania dotyczqce ragadnienia ,chrystologii politycznej”, tłum. M. Starnawska, „Concilium” 1968, nr 2, s. 330.

/// Schmitt C. 2000. Teologia polityczna, [w:] tegoż, Teologia polityczna $i$ inne pisma, tłum. M. Cichocki, Społeczny Instytut Wydawniczy Znak, Fundacja im. Stefana Batorego, Kraków-Warszawa, s. 33-83.

/// Stroumsa G. 1999. Early Christianity as Radical Religion, [w:] Barbarian Philosophy: The Religious Revolution of Early Christianity, Mohr Siebeck, Tübingen, s. 8-27.

/// Taubes J. 2010. Teologia polityczna świetego Pawła, tłum. M. Kurkowska, Wydawnictwo Naukowe PWN, Fundacja Świętego Mikołaja, Redakcja „Teologii Politycznej”, Warszawa. 
/// Taubes J. 2013. Apokalipsa i polityka. Eseje mesjanskie, tłum. P. Graczyk, R. Kuczyński, A. Kujawa-Eberharter, B. Kuźniarz, A. Lipszyc, K. Marulewska, P. Nowak, T. Ososiński, R. Pawlik, M. Rychter, A. Serafin, P. Sosnowska, Biblioteka kwartalnika KRONOS, Fundacja Augusta hr. Cieszkowskiego, Warszawa.

/// Tertulian. 1947. Apologetyk, tłum. J. Sajdak, Księgarnia Akademicka, Poznań.

/// Tertulian. 1983. Dopogan, tłum. E. Stanula, [w:] Wybórpism II, Akademia Teologii Katolickiej, Warszawa.

/// Trybusiewicz J. 1968. De Maistre, Wiedza Powszechna, Warszawa.

/// Valadier P. 2010. Nędza polityki i moc religii, tłum. T. Żeleźnik, Instytut Wydawniczy PAX, Warszawa.

/// Van Nuffelen P. 2010. Varro's Divine Antiquities: Roman Religion as an Image of Truth, „Classical Philology” 2010, nr 2 s. 162-188.

/// Vidal-Naquet P. 2003. Ateny i Atlantyda, Struktura $i$ znaczenie mitu platonskiego, tłum. L. Trzcionkowski, [w:] Czarny Lowca. Formy myśli i formy zycia społecznego w śniecie greckim, Prószyński i S-ka, Warszawa, s. 331-352.

/// Wergiliusz. 1987. Eneida, tłum. Z. Kubiak, PIW, Warszawa. 